\title{
Tinjauan Perilaku Dinamik Balok T dengan Perkuatan $C$ FR P Jenis wrap (STUDI EKSPERIMENTAL, BALOK BETON BERTULANG)
}

\section{Review of Beam Dynamic Behayior with Wrap Type Strengthening CFRP (Experimental Study, Reinforced Concrete Beams)}

\author{
Johanes B. Muda ${ }^{1)}$, B. Supriyadi ${ }^{2}$, Muslikh ${ }^{3)}$, and S. Siswosukarto ${ }^{4)}$ \\ 1) Departement of Civil and Environmental Engeneering, Universitas Gadjah Mada, Jl. Grafika, Kampus No.2, Senolowo, Sinduadi, Kec. \\ Mlati, Kabupaten Sleman, Daerah Istimewa Yogyakarta 55284 \\ Email: johanes.muda@gmail.com \\ ${ }^{2)}$ Departement of Civil and Environmental Engeneering, Universitas Gadjah Mada, Jl. Grafika, Kampus No.2, Senolowo, Sinduadi, Kec. \\ Mlati, Kabupaten Sleman, Daerah Istimewa Yogyakarta 55284 \\ 3) Departement of Civil and Environmental Engeneering, Universitas Gadjah Mada, Jl. Grafika, Kampus No.2, Senolowo, Sinduadi, Kec. \\ Mlati, Kabupaten Sleman, Daerah Istimewa Yogyakarta 55284 \\ ${ }^{4)}$ Departement of Civil and Environmental Engeneering, Universitas Gadjah Mada, Jl. Grafika, Kampus No.2, Senolowo, Sinduadi, Kec. \\ Mlati, Kabupaten Sleman, Daerah Istimewa Yogyakarta 55284
}

\begin{abstract}
ABSTRAK
Penggunaan CFRP sebagai pilihan dalam revitalisasi komponen struktur saat ini sangat banyak digunakan dan di kembangkan. Penggunaan $C F R P$ bertujuan untuk meningkatkan kapasitas lentur dan geser balok, namun pada penerapannya penambahan $C F R P$ berpengaruh terhadap perubahan kekakuan dan pola keruntuhan balok tersebut. Perilaku dinamik dari komponen struktuktur dalam penelitian ini digambarkan oleh nilai frekuensi alami komponen struktur dalam pengujian lentur dan geser. Penelitian ini menggunakan enam buah benda uji yaitu tiga benda uji balok $\mathrm{T}$ dengan perkuatan $C F R P$ wrap pengujian lentur $\left(\mathrm{BC}_{1}, \mathrm{BFR}_{1}, \mathrm{BFR}_{2}\right)$ dan tiga benda uji balok $\mathrm{T}$ dengan perkuatan $C F R P$ wrap pengujian geser $\left(\mathrm{BC}_{\mathrm{g}}, \mathrm{BC} 1_{\mathrm{g}}, \mathrm{BC} 2_{\mathrm{g}}\right)$. Dari hasil pengujian, penambahan perkuatan $C F R P$ meningkatkan nilai frekuensi alami benda uji $\mathrm{BFR} \mathrm{1}_{1}$, $\mathrm{BFR}_{2}, \mathrm{BC}_{\mathrm{g}}, \mathrm{BC}_{\mathrm{g}}$ berturut-turut sebesar $41.29 \%, 42.86 \%, 10.34 \%, 15 \%$. Peningkatan frekuensi alami ini juga divalidasi dengan adanya peningkatan kekakuan benda uji $\mathrm{BFR}_{1}, \mathrm{BFR}_{2}, \mathrm{BC}_{\mathrm{g}}, \mathrm{BC}_{\mathrm{g}}$ berturut-turut sebesar 2.08\%, 20.50\%, 65.68\%, 107.2\%. Dari hasil pengujian lentur benda uji tanpa perkuatan $\left(\mathrm{BC}_{1}\right)$ mengalami penurunan nilai frekuensi dari kondisi awal ke kondisi runtuh sebesar $29.8 \%$, lebih besar dari benda uji dengan perkuatan $\mathrm{BFR}_{1}(10.33 \%)$ dan $\mathrm{BFR}_{2}(20.13 \%)$. Sedangkan pada pengujian geser benda uji tanpa perkuatan $\left(\mathrm{BC}_{\mathrm{g}}\right)$ mengalami penurunan nilai frekuensi dari kondisi awal ke kondisi runtuh sebesar $9.58 \%$, lebih besar dari benda uji dengan perkuatan $\mathrm{BC} 1_{\mathrm{g}}$ $(7.10 \%)$ dan $\mathrm{BC}_{2} \mathrm{~g}(6.74 \%)$. Dari data hasil pengujian ini dapat disimpulkan bahwa terdapat peningkatan nilai frekuensi alami balok T dan penambahan kekakuan balok $\mathrm{T}$ akibat adanya penambahan perkuatan CFRPwrap pada balok $\mathrm{T}$ yang mana dalam kondisi awal hanya bertujuan untuk meningkatkan kapasitas lentur dan geser balok $\mathrm{T}$ tersebut.
\end{abstract}

Kata kunci: CFRP, Balok T, Frekuensi alami, Perkuatan

\begin{abstract}
The use of CFRP as an option in the revitalization of the components of the current structure is very widely used and developed. The use of CFRP aims to increase the bending and shear capacity of the beam, but in its application the addition of CFRP affects changes in the stiffness and pattern of the beam's collapse. The dynamic behavior of the components in this study is illustrated by the natural frequency value of structural components in bending and shear testing. The study used six test objects, that is three T beam test objects with CFRPwrap of bending testing. $\left(\mathrm{BC}_{1}, \mathrm{BFR}_{1} \mathrm{BFR} 2\right)$ and three $\mathrm{T}$ beam test objects with CFRPwrap of shear testing $\left(\mathrm{BC}_{\mathrm{g}, \mathrm{BC}} \mathrm{B}_{\mathrm{g}} \mathrm{BC} 2_{\mathrm{g}}\right.$. From the test results, the addition of CFRP strengthener increases the natural frequency value of $\mathrm{BFR}_{1}$ test objects, $\mathrm{BFR}_{2}, \mathrm{BC}_{\mathrm{g}}, \mathrm{BC} 2_{\mathrm{g}}$ consecutively by $41.29 \%$, $42.86 \%, 10.34 \%, 15 \%$. This increase in natural frequency was also validated by an increase in the stiffness of $\mathrm{BFR}_{1}, \mathrm{BFR}_{2}, \mathrm{BC} 1_{\mathrm{g}}, \mathrm{BC} 2_{\mathrm{g}}$ test objects consecutively by $2.08 \%, 20.50 \%, 65.68 \%, 107.2 \%$. From the results of bending test objects without strengthened $\left(\mathrm{BC}_{\mathrm{g}}\right)$ decreased the frequency value from the initial condition to the collapse conditions by $29.8 \%$, this value greater than the test object with the strengthened $\mathrm{BFR}_{1}(10.33 \%)$ and $\mathrm{BFR}_{2}(20.13 \%)$. Meanwhile, in unstrengthened test object of shear test (BCg) experienced a decrease in natural frequency value from the initial condition to a collapse condition by $9.58 \%$, this value greater than the test object with $\mathrm{CFRP}$ test object $\mathrm{BC} 1_{\mathrm{g}}$ $(7.10 \%)$ and $\mathrm{BC}_{2},(6.74 \%)$. From the data of this test result can be concluded that there is an increase in the natural frequency value of the $\mathrm{T}$ beam and the addition of stiffness of the $\mathrm{T}$ beam due to the addition of CFRPwrap strengthener on the $\mathrm{T}$ beam which in the initial condition only aims to increase the bending and shear capacity of the T beam.

Keywords: CFRP, T Beam, The Natural Frequency, strengthening
\end{abstract}




\section{PENDAHULUAN}

Penggunaan Fiber Reinforced Plastic sebagai pilihan dalam revitalisasi komponen struktur saat ini sangat banyak digunakan dan dikembangkan. Dilihat dari kemudahan instalasi di lapangan dan bahan yang ringan namun memiliki kekuatan yang baik sebagai bahan retrofit membuat FRP banyak diminati sebagai solusi utama ketika waktu dan lokasi khusus sebagai kebutuhan utamanya. Ada beberapa jenis FRP yang digunakan sebagai bahan retrovit, namun yang sering digunakan sebagai perkuatan balok yaitu Glass Fiber Reinforced Polymer (GFRP) dan Carbon Fiber Reinforced Polymer (CFRP). Penggunaan FRP sebagai bahan perkuatan komponen struktur di Indonesia masih sangat kekurangan informasi, terutama code SNI saat ini yang belum secara khusus mengatur penggunaan FRP. Saat ini code yang digunakan sebagai acuan dalam penggunaan $F R P$ merujuk pada ACI 440.

FRP yang digunakan dalam penelitian ini berupa Carbon Fiber Reinforced Polymer (CFRP) wrap yang digunakan sebagai perkuatan untuk balok $\mathrm{T}$ pada pengujian lentur dan geser. Perkuatan ini dimaksudkan dengan tujuan awal untuk meningkatkan kapasitas lentur dan geser, namun penelitian ini meninjau frekuensi alami dan kekakuan untuk mengetahui pengaruh perkuatan ini terhadap perilaku dinamik balok tersebut. Apakah ada perubahan perilaku dinamik terhadap penggunaan CFRP sebagai perkuatan pada balok T? Atau adakah pengaruh penggunaan CFRP terhadap kekauan balok $\mathrm{T}$ tersebut? Dalam mengumpulkan informasi mengenai perkuatan struktur menggunakan $C F R P$ dilakukan penelitian secara eksperimen untuk mengetahui seberapa besar pengaruh dari perkuatan itu terhadap kekakuan dan perilaku dinamik Balok $\mathrm{T}$ itu sendiri. Hal ini menjadi dasar dilakukannya penelitian ini. Pada akhirnya kajian ini diharapkan dapat memberikan informasi tambahan yang berguna dalam pertimbangan penggunaan $C F R P$ sebagai bahan perkuatan struktur.

Arjanto (2002) melakukan penelitian tentang perilaku dinamik balok beton bertulang retrofit dengan CFRP wrap. Hasil penelitian menunjukkan bahwa perilaku frekuensi alami balok yang diperkuat sama dengan balok bertulang biasa dimana frekuensi alami balok rusak lebih rendah dari balok utuh. Perilaku rasio redaman balok yang diperkuat sama dengan balok beton bertulang biasa, dimana redaman balok rusak lebih besar dibanding dengan balok utuh. Nilai frekuensi alami dapat dinyatakan dengan persamaan:

$$
f=\frac{1}{2 \pi} \sqrt{\frac{k}{m}}
$$

dimana :

$f \quad=$ frekuensi alami $(\mathrm{Hz})$

$k=$ kekakuan struktur $(\mathrm{N} / \mathrm{mm})$

$m \quad=$ massa dari struktur $\left(\mathrm{N} . \mathrm{s}^{2} / \mathrm{mm}\right)$
Han Ay Lie dkk (2018) dalam penelitiannya terkait penggunaan CFRP (wrap) pada balok beton bertulang dengan penampang $\mathrm{T}$, menunjukan bahwa kapasitas pemikulan balok meningkat $62 \%$ pada balok dengan perkuatan FRP yang gagal akibat putusnya FRP, dan $47 \%$ pada balok dengan perkuatan FRP yang runtuh karena debounding FRP. Lepasnya ikatan antara lembaran FRP dengan beton menurunkan kapasitas pemikulan sebesar 15 $\%$.

Mesay A. Endeshaw dkk (2008) dalam penelitian Retrofit Of Rectangular Bridge Columns Using CFRP Wrapping menunjukan bahwa dengan menggunakan $C F R P$ wrap pada retrovit meningkatkan peforma seismic dari struktur eksisting Hasil penelitian ini memberikan dasar untuk mengevaluasi dan meningkatkan kinerja seismik kolom jembatan persegi panjang yang ada di Negara Bagian Washington. Untuk retrofitting kolom persegi panjang, disarankan agar jaket berbentuk oval digunakan bila memungkinkan. Jaket oval dapat disediakan dengan bahan baja atau CFRP. Kedua jenis jaket memberikan tingkat kurungan yang sebanding yang membatasi strain lingkaran melintang hingga di bawah 1000 mikrostrain dan yang menghasilkan kolom daktail. Kinerja, detail dan prosedur untuk desain jaket baja berbentuk oval disediakan dalam FHWA Seismic Retrofitting Manual for Highway Bridges (2006). Pedoman desain untuk jaket CFRP berbentuk oval diberikan dalam ACTT-95/08 (Seible et al., 1995).

Januar dan Triwiyono (2003) dalam penelitiannya menunjukan bahwa penggunaan CFRP sebagai perkuatan kolom yang dipasang dengan arah serat radial (carbon fibre jacket) menunjukan bahwa kemampuan kolom tersebut dalam menahan beban lateral meningkat $75.566 \%$ (pada balok serupa dengan beban geser).

Cosmas (2015) melakukan penelitian tentang perilaku dinamik pelat lantai semi precast. menyimpulkan ada perbedaan frekuensi alami dari tiap jenis pelat pada kondisi sebelum dibebani yaitu pelat monolit sebesar $14,84 \mathrm{~Hz}$, Pelat komposit tanpa shear connector sebesar $13,45 \mathrm{~Hz}$, Pelat komposit jarak antar shear connector L/4(100) - L/2(150) - L/4(100) sebesar 13,62 Hz, Pelat komposit jarak antar shear connector L/3(100) - L/3(150) L/3(100) sebesar 13,46 Hz dan Pelat komposit jarak antar shear connector $100 \mathrm{~mm}$ sebesar $15,97 \mathrm{~Hz}$ dan juga ada penurunan frekuensi alami seiring besarnya penurunan frekuensi alami. Displacement mode pelat utuh lebih kecil dibandingkan pelat rusak dan displacement mode terbesar terjadi pada tengah bentang, curvature mode dan beda absolut curvature mode menunjukan adanya kerusakan pada pelat. Pola retak yang terjadi pada pelat monolit dan komposit umumnya retak lentur dan terjadi ditengah bentang.

Widorini (2012) melakukan pengujian dinamik pada panel pelat lantai monolit dan komposit. Hasil pengujian 
oleh Widorini menunjukkan bahwa Pelat Monolit lebar 200 (pelat cast in situ) dan pelat Komposit lebar 200 (pelat semi precast) memiliki frekuensi alami yang sama yaitu 16,17 Hz. Pada pelat Monolit lebar 400 (pelat cast in situ) memiliki frekuensi alami $16,94 \mathrm{~Hz}$ dan pelat komposit lebar 400 (pelat semi precast) memiliki frekuensi alami $15,87 \mathrm{~Hz}$, penurunan frekuensi alami sebesar $6,32 \%$. Pelat komposit mengalami penurunan frekuensi alami $1,86 \%$ dengan bertambahnya panel sedangkan pada pelat monolit naik 4,76\%. Hasil eksperimen mode displacement menunjukkan hasil bahwa pelat yang ada kerusakan mempunyai displacement lebih besar. Curvature mode cukup dapat menunjukkan indentifikasi adanya kerusakan. Pola retak yang terjadi untuk pelat monolit maupun pelat precast dimulai di daerah tengah bentang dan pada beban maksimum pola retak saat runtuh mengalami kegagalan lentur.

Penelitian oleh Tuhuteru (2013) meninjau pengaruh dari jarak dan penambahan shear connector terhadap perilaku dinaik pada pelat lantai monolit dan komposit. Hasil pengujian pada penelitian ini mendapatkan bahwa PM400, PK400-SC100 dan PK400-SC200 kondisi pelat utuh memiliki frekuensi alami yang sama yaitu $15,5 \mathrm{~Hz}$, sedangkan PK400-SC300 memiliki frekuensi alami 14,77 $\mathrm{Hz}$, dan PM400-TSC kondisi pelat utuh memiliki frekuensi alami yaitu 14,53 Hz. Frekuensi alami sistem struktur pelat rusak mengalami penurunan frekuensi alami pada pelat monolit maupun pelat komposit. Kondisi ini diakibatkan karena terjadinya penurunan kekakuan pada pelat akibat kerusakan.

Pada aplikasinya CFRP membutuhkan epoxy sebagai perekat (adhesive layer) agar balok dan CFRP dapat bersifat komposit. Kekakuan geser (Ks) dan kekakuan normal $(\mathrm{Kn})$ dari adhesive layer dapat dianalisa dengan model Ziraba et al (1994).

$$
\begin{aligned}
& K_{s}=\frac{G_{a} b_{a}}{t_{a}} \\
& K_{n}=\frac{E_{a} b_{a}}{t_{a}}
\end{aligned}
$$

Dimana :

$$
\begin{aligned}
\mathrm{E}_{\mathrm{a}} & =\text { Modulus elastisitas } \\
\mathrm{G}_{\mathrm{a}} & =\text { Modulus Geser } \\
\mathrm{b}_{\mathrm{a}} & =\text { Lebar adhesive layer } \\
\mathrm{t}_{\mathrm{a}} & =\text { Tebal adhesive layer }
\end{aligned}
$$

Kekakuan menurut Gere dan Timoshenko (1987) didefinisikan sebagai gaya yang dibutuhkan untuk menghasilkan suatu lendutan sebesar satu satuan, nilai kekakuan merupakan kemiringan garis dari hubungan antara beban dan lendutan,

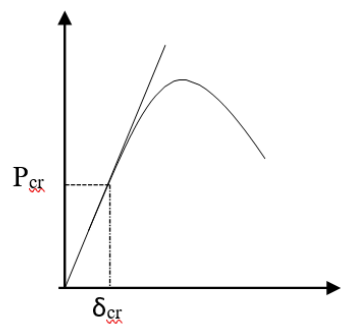

Gambar 1. Grafik pendekatan kekakuan.

Nilai kekakuan dapat dihitung berdasarkan rasio beban dan lendutan.

$$
K=\frac{P_{c r}}{\delta_{c r}}
$$

Dimana :

$\begin{array}{ll}\mathrm{P}_{\mathrm{cr}} & =\text { Beban pada saat firstcrack } \\ \delta_{\mathrm{cr}} & =\text { lendutan pada saat firstcrack }\end{array}$

Kerusakan struktur akan mempengaruhi matrik kekakuan sedangkan matrik massa adalah tetap, sehingga kerusakan balok dapat dideteksi dengan berubahnya karakteristik dinamis balok, yaitu menurunnya frekuensi alami dan berubahnya ragam alami getaran. Persamaan untuk menyelesaikan masalah tersebut dikenal dengan persamaan eigen problem sebagai berikut:

Pada balok utuh :

$$
\text { [K_s ]- } \omega^{\wedge} 2\left[\mathrm{M} \_\mathrm{s}\right]\{\alpha\}=\{0\}
$$

Pada balok rusak :

$$
\left[\llbracket \mathrm{K}^{\prime} \rrbracket \_\mathrm{s}\right]-\llbracket \omega^{\prime} \rrbracket^{\wedge} 2\left[\mathrm{M} \_\mathrm{s}\right]\left\{\alpha^{\prime}\right\}=\{0\}
$$

Dimana:

$$
\begin{array}{ll}
\mathrm{Ks} & =\text { matrik kekakuan sistem utuh } \\
\mathrm{K} \text { 's } & =\text { matrik kekakuan sistem rusak } \\
\mathrm{Ms} & =\text { matrik masa sistem utuh atau rusak } \\
\omega & =\text { frekuensi alami sistem utuh } \\
\omega^{\prime} & =\text { frekuensi alami sistem rusak } \\
\alpha & =\text { mode dari sistem utuh } \\
\alpha^{\prime} & =\text { mode dari sistem rusak }
\end{array}
$$

Analisis tegangan dan regangan dapat dilakukan dengan menggunakan persamaan berikut: untuk kondisi elastis,

$$
\mathrm{f}_{\mathrm{y}}=\varepsilon \times \mathrm{E},
$$

Sedangkan untuk kondisi strain hardening (fs) dapat dihitung menggunakan persamaan berikut:

$$
\begin{gathered}
\mathrm{F}_{\mathrm{s}}=\mathrm{F}_{\mathrm{y}}[(\mathrm{mp}+2) /(60 \mathrm{p}+2)+\mathrm{p}(60-\mathrm{m}) / 2 \mathrm{n}] \\
\mathrm{m}=\left[\mathrm{n}\left(\mathrm{F}_{\mathrm{su}} / \mathrm{F}_{\mathrm{y}}\right)-60 \mathrm{q}-1\right] /\left(15 \mathrm{q}^{2}\right) \\
\mathrm{n}=(30 \mathrm{q}+1)^{2} \\
\mathrm{p}=\varepsilon_{\mathrm{s}}-\varepsilon_{\mathrm{sh}} \\
\mathrm{q}=\varepsilon_{\mathrm{su}}-\varepsilon_{\mathrm{sh}}
\end{gathered}
$$

Dimana :

$$
\begin{aligned}
& \text { Fy } \quad=\text { Tegangan leleh baja }(\mathrm{N} / \mathrm{mm} 2) \\
& \text { Fs } \quad=\text { Tegangan strain hardening baja } \\
& (\mathrm{N} / \mathrm{mm} 2) \\
& \text { Fsu }=\text { Tegangan ultimit baja }(\mathrm{N} / \mathrm{mm} 2) \\
& \text { ssu } \quad=\text { Regangan ultimit baja } \\
& \text { Esh } \quad=\text { Regangan strain hardening baja } \\
& \varepsilon \quad=\text { Regangan baja }
\end{aligned}
$$




\section{METODE}

Benda uji berupa balok beton bertulang tampang $\mathrm{T}$ dengan jumlah 6 benda uji. 3 benda uji pengujian lentur dan 3 benda uji pengujian geser. Masing-masing pengujian memiliki Satu benda uji digunkan sebagai balok kontrol dengan kode $\mathrm{BC}_{\mathrm{l}}$ untuk pengujian lentur dan $\mathrm{BC}_{\mathrm{g}}$ untuk pengujian geser. Dua benda uji masing-masing pengujian diberikan perkuatan

dengan CFRPwrap yaitu $\mathrm{BFR}_{1}$ (perkuatan lentur sepanjang bentang), $\mathrm{BFR}_{2}$ (perkuatan lentur sepanjang setengah bentang), BC1g (perkuatan geser pada area geser model Uwrap) dan $\mathrm{BC} 2 \mathrm{~g}$ (perkuatan geser pada area geser model Ustrip sudut $45^{\circ}$ ). Benda uji balok $\mathrm{T}$ dapat dilihat pada Gambar 1 dan Gambar 2.

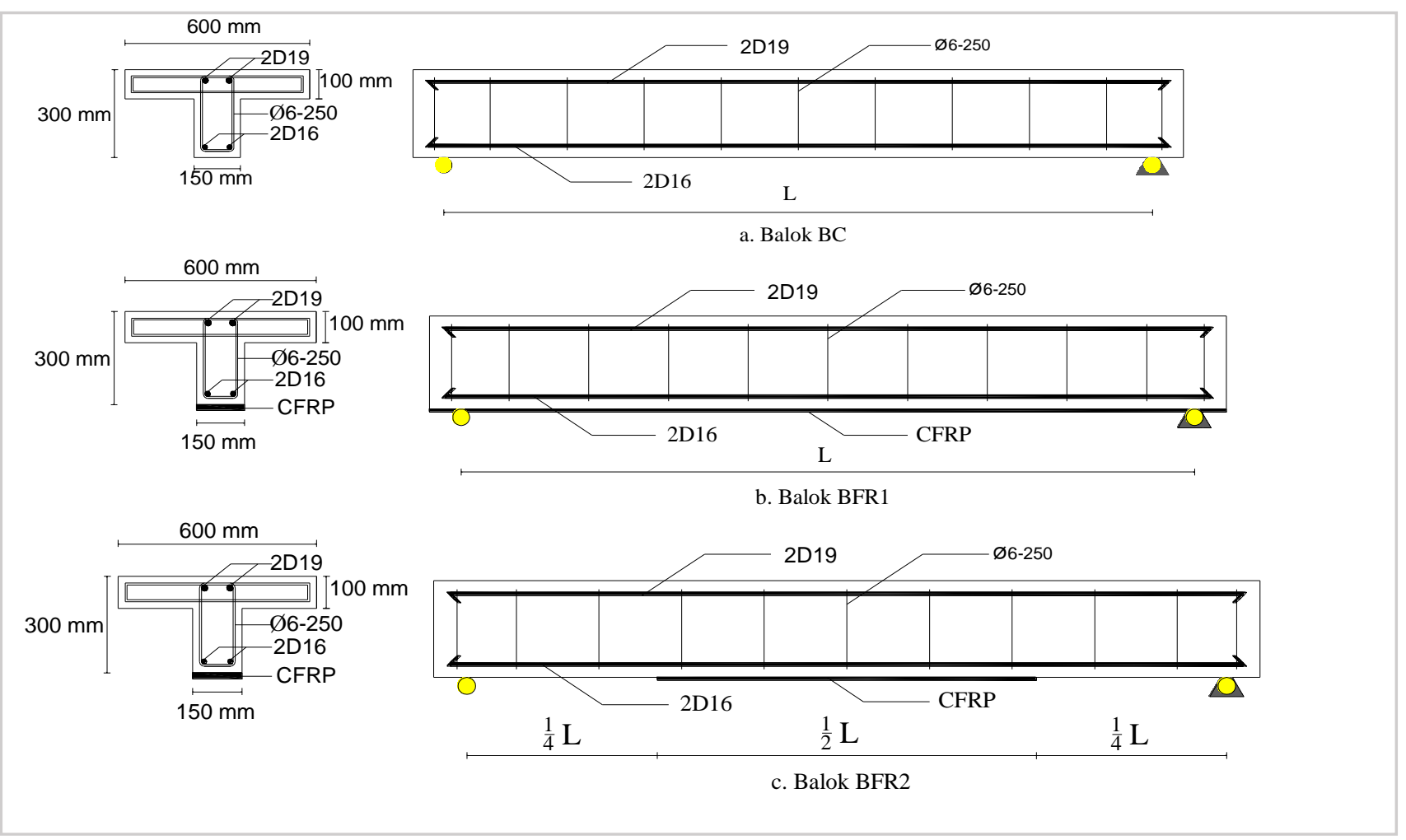

Gambar 2. Benda Uji Balok T Pengujian Lentur.

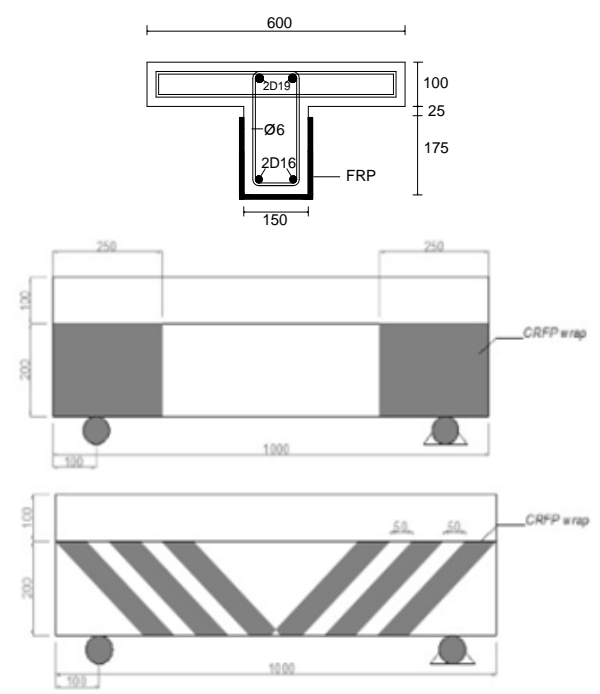

Gambar 3. Benda Uji Balok T Pengujian Geser. 
Mutu beton yang digunkan adalah 29,04 MPa. Perkuatan CFRPwrap menggunakan Sika Wrap 231C dan epoxy antara beton dengan CFRP menggunakan Sikadur 330 dari produk SIKA. Pengujian dilakukan setelah beton berumur lebih dari 28 hari. Pengujian ini dilakukan dengan memberikan getaran bebas (free vibration) pada struktur dengan cara memukul benda uji secara perlahan-lahan. Hasil dari getaran tersebut diambil dengan velocityometer yang diletakkan pada salah satu titik pada permukaan balok dan dihubungkan dengan program Dewe pada komputer. Data berupa rekaman getaran-waktu. Pengujian ini dilakukan dengan 4 kondisi pengujian untuk setiap specimen baik lentur maupun geser.

Adapun tahapan pengujian yaitu:

1) Pengujian frekuensi kondisi awal

2) Pembebanan statis hingga firstcrack.
3) Pengujian frekuensi kondisi firstcrack.

4) Instalasi perkuatan $C F R P$

5) Pengujian frekuensi kondisi $C F R P$

6) Pemberian beban statis berulang

7) Pembebanan statis hingga runtuh

8) Pengujian frekuensi kondisi Runtuh

Set up pengujian ditunjukkan pada Gambar 3, metode pembebanan dilakukan 2 titik pada pengujian lentur dengan tujuan tidak ada pengaruh tegangan geser pada tengah bentang. Dan pembebanan 1 titik pada pengujian geser. Beban yang diterima oleh balok dibaca oleh load cell, deformasi pada balok akan dibaca oleh LVDT (Linier Vertical Displacement Transducer), regangan pada beton akan dibaca oleh strain gauge tipe KC-70-A1-11 dan regangan pada baja akan dibaca oleh strain gauge tipe N11FA-8-120-11.

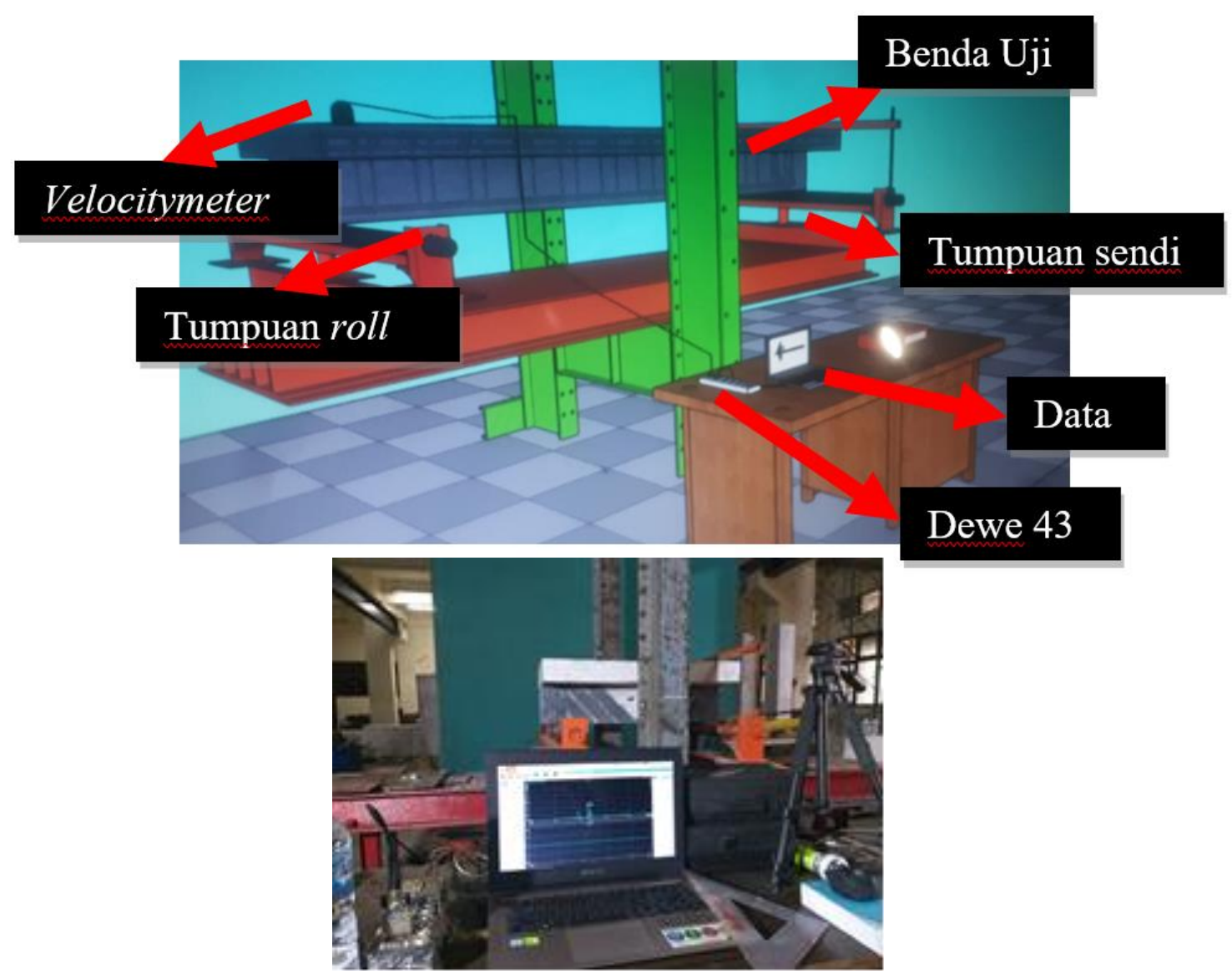

Gambar 4. Setting Up Pengujian

\section{HASIL DAN PEMBAHASAN}

\section{Frekuensi Alami}

Hasil pengujian frekuensi balok $\mathrm{T}$ berupa rekaman dengan data frekuensi setiap satuan waktu. Data ini kemudian dianalisis FFT dan difilter untuk memudahkan pembacaan antara frekuensi alami dan noise. Contoh data rekaman dapat dilihat pada Gambar 4. Perkuatan CFRP pada balok
T dapat meningkatkan nilai frekuensi alami balok tersebut. Penambahan perkuatan ini juga meningkatkan kekakuan balok T. Setelah terjadinya demage pada saat firstcrack frekuensi alami dan kekakuan balok T menurun. Hal ini sejalan dengan penelitian-penelitian lain yang menyatakan penurunan frekuensi alami meningkat dengan

\section{4 dinamika TEKNIK SIPIL}


pertambahan kerusakan pada balok. Setelah penurunan frekuensi alami dan kekakuan ini balok diperkuat dengan CFRPwrap pada 4 benda uji. Hasil pengujian pada 4 benda uji ini menunjukan bahwa penambahan perkuatan CFRP meningkatkan nilai frekuensi alami yang sebelumnya turun akibat bertambahnya demage. Hasil pengujian dabat dilihat pada Table 1 dan Gambar di bawah ini.

Tabel 1. Hasil Pengujian Frekuensi

\begin{tabular}{|c|c|c|c|c|c|c|c|c|}
\hline \multirow{3}{*}{ No } & \multirow{3}{*}{$\begin{array}{c}\text { Benda Uji } \\
\text { Balok T }\end{array}$} & \multirow{3}{*}{$\begin{array}{c}\text { Panjang (L) } \\
\mathrm{mm}\end{array}$} & \multirow{3}{*}{$\begin{array}{l}1 / 4 \mathrm{~L} \\
\mathrm{~mm}\end{array}$} & \multicolumn{4}{|c|}{ Frekuensi Alami (Hz) } & \multirow{3}{*}{ Keterangan } \\
\hline & & & & \multicolumn{4}{|c|}{ Kondisi Pengujian } & \\
\hline & & & & Awal & First Crack & CFRP & Runtuh & \\
\hline 1 & $\mathrm{BC}_{1}$ & 2500 & 625 & 13.92 & 11.91 & - & 9.77 & Benda Uji lentur \\
\hline 2 & $\mathrm{BFR}_{1}$ & 2500 & 625 & 12.3 & 12.06 & 17.04 & 13.57 & Benda Uji lentur \\
\hline 3 & $\mathrm{BFR}_{2}$ & 2500 & 625 & 11.87 & 11.62 & 16.6 & 14.26 & Benda Uji lentur \\
\hline 4 & $\mathrm{BCg}$ & 1000 & 250 & 16.8 & 16.26 & - & 15.19 & Benda Uji geser \\
\hline 5 & $\mathrm{BClg}$ & 1000 & 250 & 15.77 & 15.67 & 17.29 & 14.65 & Benda Uji geser \\
\hline 6 & $\mathrm{BC} 2 \mathrm{~g}$ & 1000 & 250 & 14.55 & 13.33 & 15.33 & 13.57 & Benda Uji geser \\
\hline
\end{tabular}

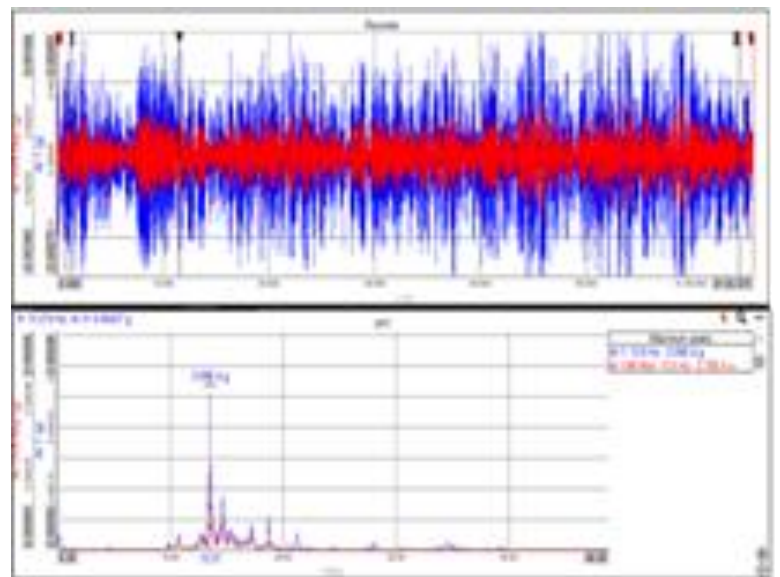

Gambar 5. Hasil Record dan Analisis FFT Balok BC2 $2_{\mathrm{g}}$ Kondisi Runtuh

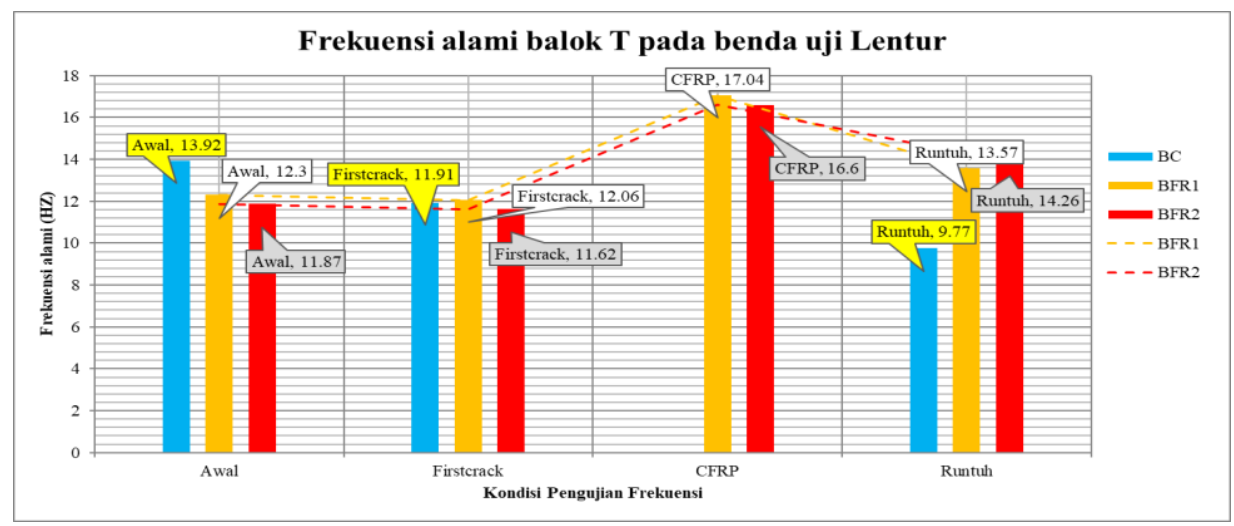




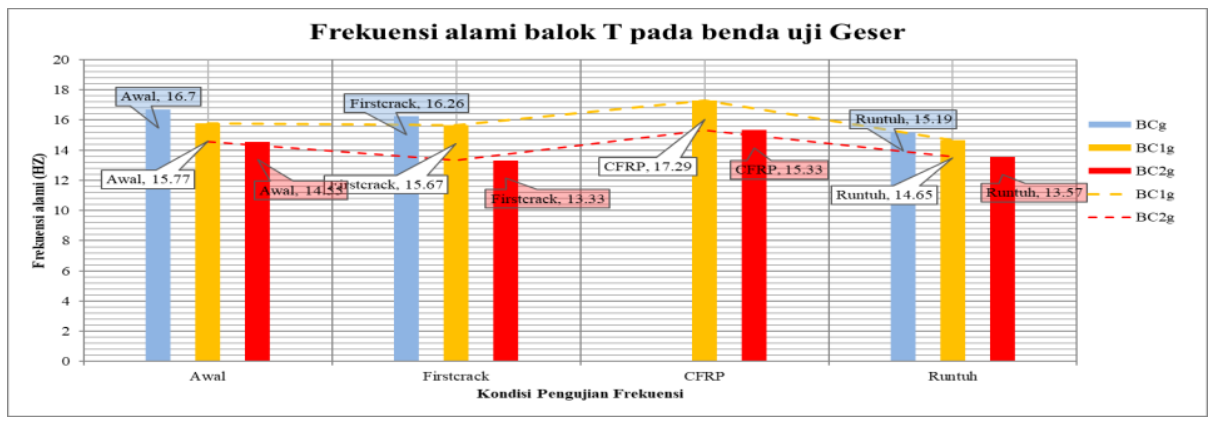

Gambar 6. Hasil Pengujian Frekuensi Alami Benda Uji Setiap Kondisi

\section{Balok kontrol lentur $\left(\mathrm{BC}_{\mathrm{l}}\right)$}

Dari table 1 diketahui bahwa pada balok $\mathrm{BC}_{1}$ selama pengujian mengalami perubahan frekuensi pada setiap kondisi pengujian. Semakin besar kerusakan pada balok T semakin kecil frekuensi alami balok tersebut. Hal ini sejalan dengan perubahan kekakuan pada balok tersebut yang dianalisis dari grafik tegangan-regangan balok $\mathrm{BC}_{\mathrm{l}}$. Perubahan frekuensi pada balok $\mathrm{BC}_{1}$ selama pengujian, grafik tegangan regangan dan perubahan kekakuan balok $\mathrm{BC}_{1}$ dapat dilihat pada Gambar 7.
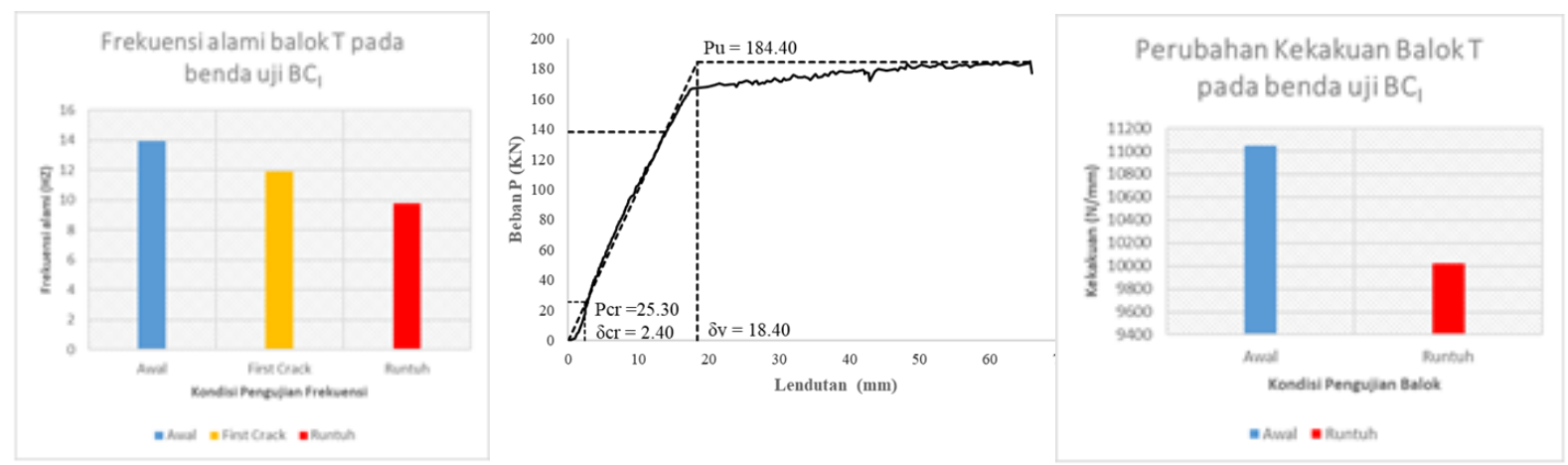

Gambar 7. Hasil Analisa Pengujian Benda $\mathrm{Uji}_{\mathrm{BC}}$

\section{Balok BFR}

Dari table 1 diketahui bahwa pada balok $\mathrm{BFR}_{1}$ selama pengujian mengalami perubahan frekuensi pada setiap kondisi pengujian. Dengan adanya penambahan CFRPwrap frekuensi balok yang sebelumnya menurun akibat retak awal mengalami peningkatan. Hal ini sejalan dengan perubahan kekakuan yang ditunjukan pada balok tersebut yang dianalisis dari grafik tegangan-regangan balok BFR ${ }_{1}$. Perubahan frekuensi pada balok $\mathrm{BFR}_{1}$ selama pengujian, grafik tegangan regangan dan perubahan kekakuan balok BFR1 dapat dilihat pada Gambar 8.
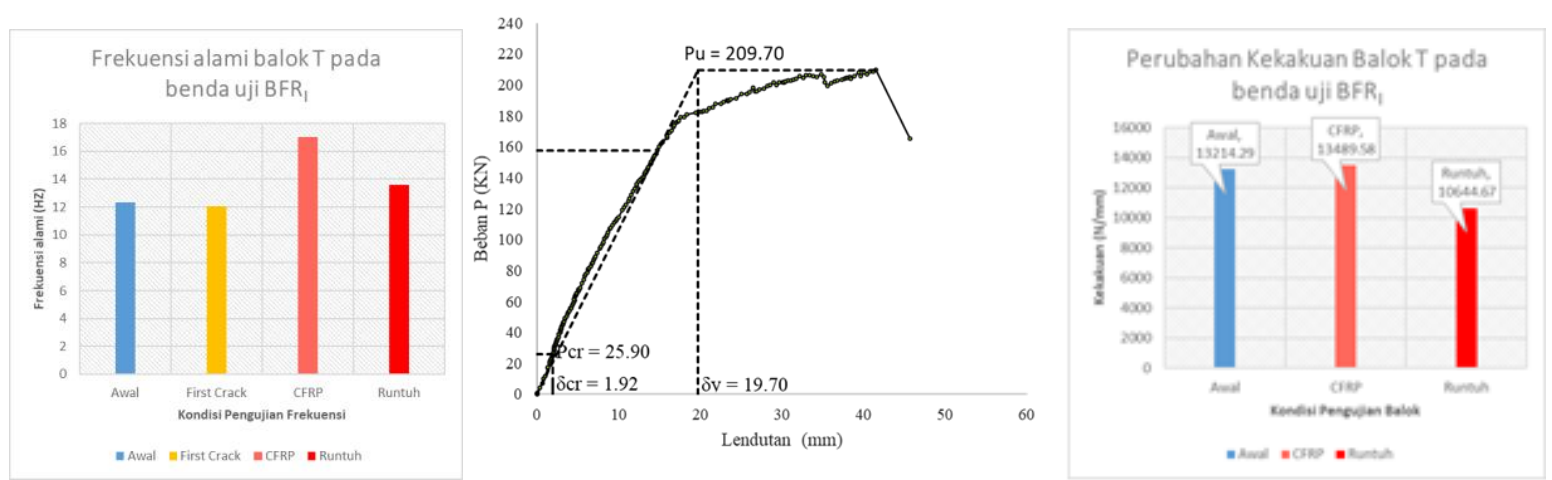

Gambar 8. Hasil Analisa Pengujian Benda Uji BFR 1 


\section{Balok BFR2}

Dari table 1 diketahui bahwa pada balok $\mathrm{BFR}_{2}$ selama pengujian mengalami perubahan frekuensi pada setiap kondisi pengujian. Dengan adanya penambahan CFRPwrap frekuensi balok yang sebelumnya menurun akibat retak awal mengalami peningkatan. Hal ini sejalan dengan perubahan kekakuan yang ditunjukan pada balok tersebut yang dianalisis dari grafik tegangan-regangan balok BFR2. Perubahan frekuensi pada balok $\mathrm{BFR}_{2}$ selama pengujian, grafik tegangan-regangan dan perubahan kekakuan balok $\mathrm{BFR}_{2}$ dapat dilihat pada Gambar 9.
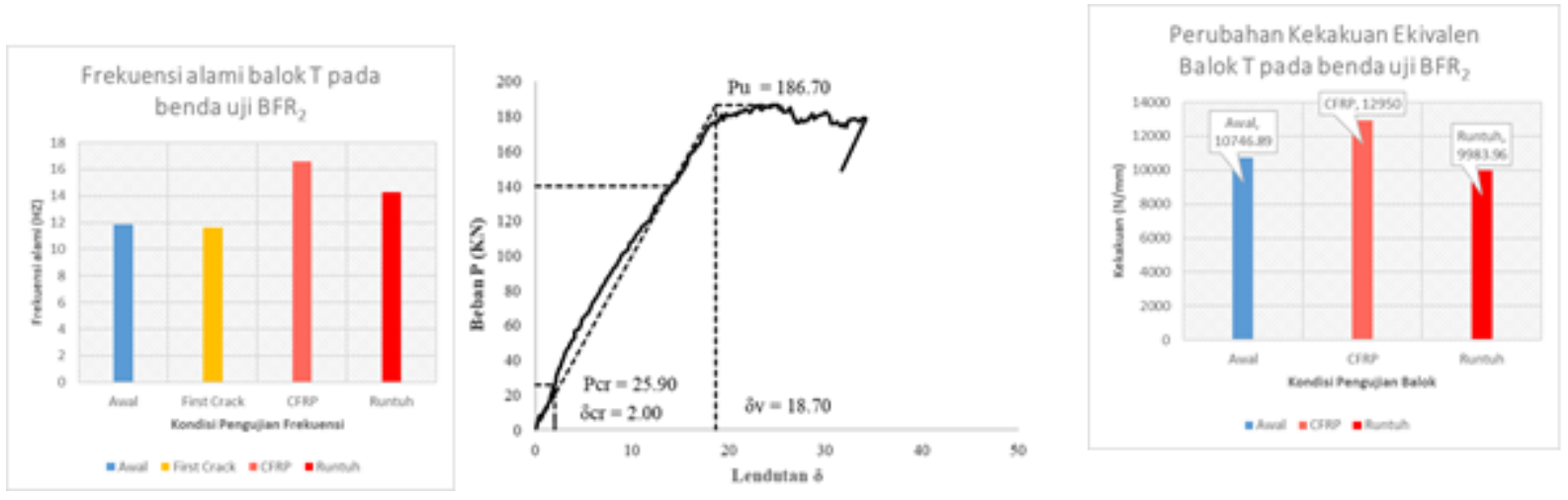

Gambar 9. Hasil Analisa Pengujian Benda Uji BFR2

\section{Balok kontrol lentur $\left(\mathrm{BC}_{\mathrm{g}}\right)$}

Dari table 1 diketahui bahwa pada balok $\mathrm{BC}_{\mathrm{g}}$ selama pengujian mengalami perubahan frekuensi pada setiap kondisi pengujian. Semakin besar kerusakan pada balok T semakin kecil frekuensi alami balok tersebut. Hal ini sejalan dengan perubahan kekakuan pada balok tersebut yang dianalisis dari grafik tegangan-regangan balok $\mathrm{BC}_{\mathrm{g}}$. Perubahan frekuensi pada balok $\mathrm{BC}_{\mathrm{g}}$ selama pengujian, grafik tegangan regangan dan perubahan kekakuan balok $\mathrm{BC}_{\mathrm{g}}$ dapat dilihat pada Gambar 10.
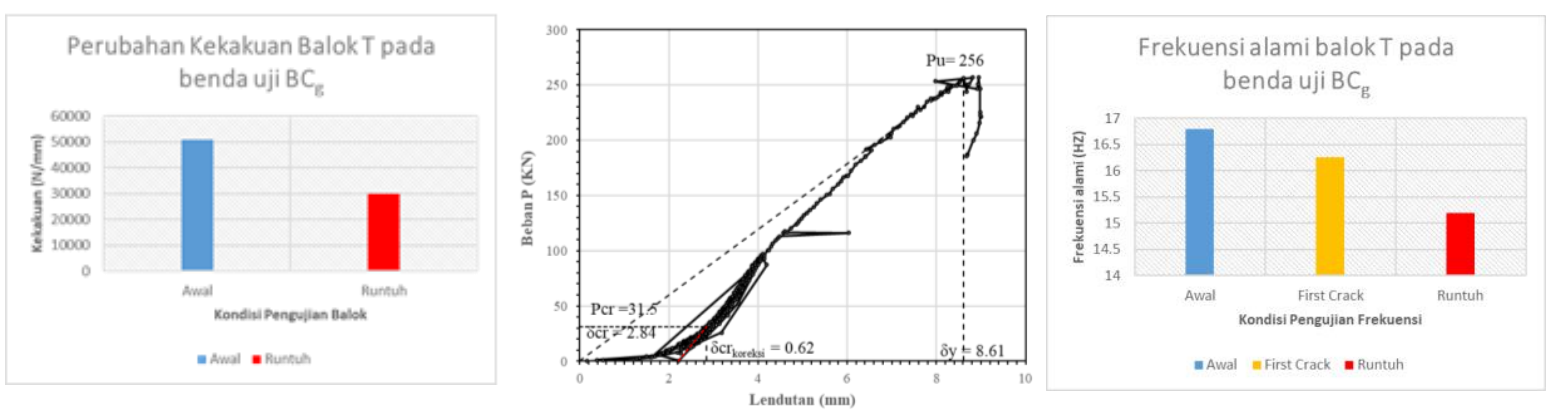

Gambar 10. Hasil Analisa Pengujian Benda Uji BCg

\section{Balok BC1 $\mathbf{g}_{\mathrm{g}}$}

Dari table 1 diketahui bahwa pada balok $\mathrm{BC}_{\mathrm{g}}$ selama pengujian mengalami perubahan frekuensi pada setiap kondisi pengujian. Dengan adanya penambahan CFRPwrap frekuensi balok yang sebelumnya menurun akibat retak awal mengalami peningkatan. Hal ini sejalan dengan perubahan kekakuan yang ditunjukan pada balok tersebut yang dianalisis dari grafik tegangan-regangan balok $\mathrm{BC} 1_{\mathrm{g}}$. Perubahan frekuensi pada balok $\mathrm{BC} 1_{\mathrm{g}}$ selama pengujian, grafik tegangan regangan dan perubahan kekakuan balok $\mathrm{BC}_{\mathrm{g}}$ dapat dilihat pada Gambar 11. 

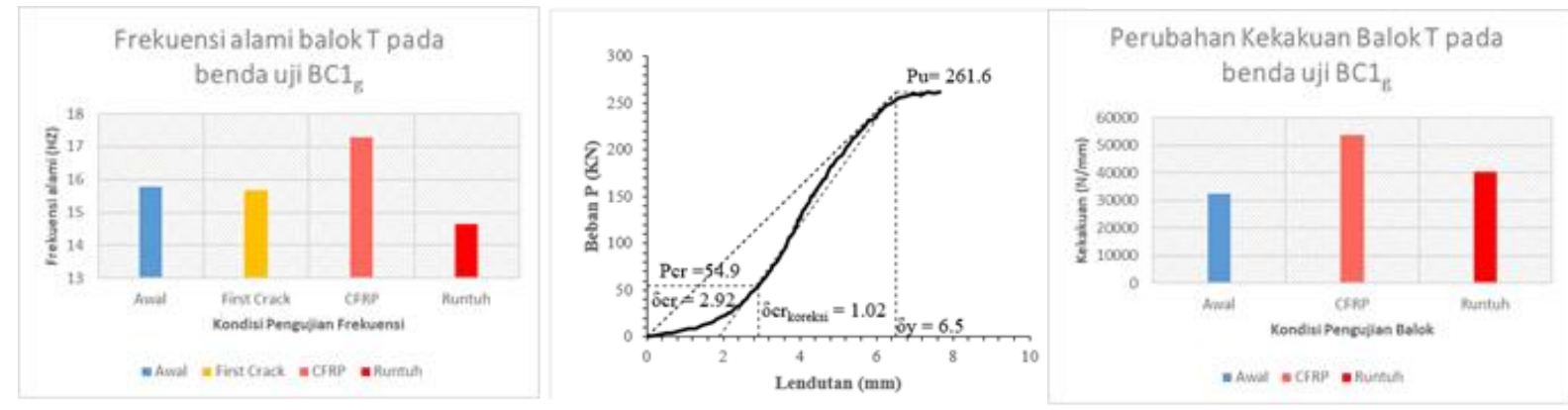

Gambar 11. Hasil Analisa Pengujian Benda Uji BC1g

\section{Balok $\mathrm{BC} 2 \mathrm{~g}$}

Dari table 1 diketahui bahwa pada balok $\mathrm{BC} 2 \mathrm{~g}$ selama pengujian mengalami perubahan frekuensi pada setiap kondisi pengujian. Dengan adanya penambahan CFRPwrap frekuensi balok yang sebelumnya menurun akibat retak awal mengalami peningkatan. Hal ini sejalan dengan perubahan kekakuan yang ditunjukan pada balok tersebut yang dianalisis dari grafik tegangan-regangan balok $\mathrm{BC} 2 \mathrm{~g}$. Perubahan frekuensi pada balok $\mathrm{BC} 2 \mathrm{~g}$ selama pengujian, grafik tegangan-regangan dan perubahan kekakuan balok BC2 $2_{\mathrm{g}}$ dapat dilihat pada Gambar 12 .
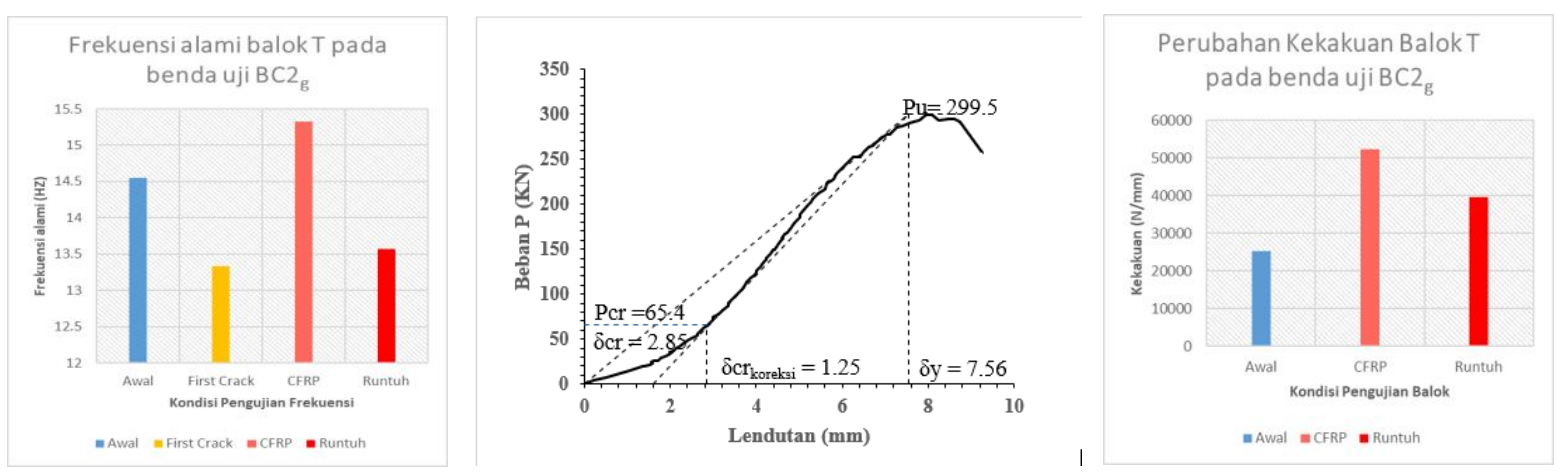

Gambar 12. Hasil Analisa Pengujian Benda Uji BC2g

\section{KESIMPULAN}

Berdasarkan hasil pengujian frekuensi yang diperoleh dan hasil analisis kekakuan benda uji dapat ditarik beberapa kesimpulan yang sesuai dengan tujuan penelitian ini antara lain:

1. Perilaku dinamik benda uji balok $\mathrm{T}$ baik benda uji lentur maupun geser sebelum penambahan perkuatan CFRPwrap ditunjukan dengan perubahan nilai frekuensi alami balok $\mathrm{BFR}_{1}, \mathrm{BFR}_{2}, \mathrm{BC}_{\mathrm{g}}$ dan $\mathrm{BC} 2_{\mathrm{g}}$ yang mengalami penurunan nilai frekuensi setelah mencapai kondisi retak awal berurutan sebesar $1.95 \%, 2.106 \%, 0.63 \%$ dan $8.38 \%$ akibat penambahan kerusakan pada benda uji setelah retak awal.

Perilaku dinamik benda uji balok $\mathrm{T}$ baik benda uji lentur maupun geser setelah penambahan perkuatan CFRPwrap ditunjukan dengan perubahan nilai frekuensi alami balok $\mathrm{BFR}_{1}, \mathrm{BFR}_{2}, \mathrm{BC}_{\mathrm{g}}$ dan $\mathrm{BC}_{\mathrm{g}}$ yang mengalami peningkatan nilai frekuensi berurutan sebesar $41.29 \%, 42.86 \%, 10.34 \%$ dan $15 \%$ akibat adanya kekakuan tambahan dari perkuatan CFRPwrap dan mengalami penurunan nilai frekuensi (akibat pembebanan berulang beban hidup dan beban statis lentur/geser hingga runtuh) masing-masing sebesar $20.36 \%, \quad 14.1 \%, 15.27 \%$ dan $11.48 \%$ akibat penambahan kerusakan pada benda uji.

2. Hasil perbandingan perilaku dinamik Balok $\mathrm{T}$ beton bertulang diperkuat $C F R P$ dan tanpa perkuatan yang diperoleh sebagai berikut:

a. Lentur

Pada benda uji lentur, balok kontrol $\mathrm{BC}_{1}$ tanpa perkuatan mengalami perubahan frekuensi yaitu penurunan frekuensi dari kondisi awal ke kondisi runtuh sebesar $29.8 \%$, sedangkan balok dengan perkuatan $\mathrm{BFR}_{1}$ dan $\mathrm{BFR}_{2}$ mengalami penurunan frekuensi dari kondisi awal ke kondisi runtuh berturut-turut sebesar $10.33 \%$ dan $20.13 \%$. Penurunan nilai frekuensi balok $\mathrm{T}$ benda uji lentur dengan perkuatan lebih kecil 
dari penurunan frekuensi balok $\mathrm{T}$ tanpa perkuatan.

b. Geser

Pada benda uji geser, balok kontrol $\mathrm{BC}_{\mathrm{g}}$ tanpa perkuatan mengalami perubahan frekuensi yaitu penurunan frekuensi dari kondisi awal ke kondisi runtuh sebesar $9.58 \%$, sedangkan balok dengan perkuatan $\mathrm{BC} 1_{\mathrm{g}}$ dan $\mathrm{BC} 2_{\mathrm{g}}$ mengalami penurunan frekuensi dari kondisi awal ke kondisi runtuh berturut-turut sebesar $7.10 \%$ dan 6.74\%. Penurunan nilai frekuensi balok T benda uji geser dengan perkuatan lebih kecil dari penurunan frekuensi balok $\mathrm{T}$ tanpa perkuatan.

3. Perubahan kekakuan benda uji balok lentur dan geser sebelum dan sesudah perkuatan CFRPwrap sebagai berikut:

a. Balok BFR $_{1}$ memiliki kekakuan awal sebesar $13214.29 \mathrm{~N} / \mathrm{mm}$ dan mengalami peningkatan nilai kekakuan setelah perkuatan menjadi $13489.58 \mathrm{~N} / \mathrm{mm}$ atau sebesar $2.08 \%$.

b. Balok $\mathrm{BFR}_{2}$ memiliki kekakuan awal sebesar $10746.89 \mathrm{~N} / \mathrm{mm}$ dan mengalami peningkatan nilai kekakuan setelah perkuatan menjadi $12950 \mathrm{~N} / \mathrm{mm}$ atau sebesar $20.50 \%$.

\section{DAFTAR PUSTAKA}

ASTM D 78C-02. 2002. Standard Test Method for Flexural Strength of Concrete (Using Simple Beam with Third-Point Loading)

ACI 318M-02. 2002. Building Code Requirements For Structural Concrete And Commentary (ACI 318RM-02)

ACI 440.2R.2017. Guide for the Design and Construction of Externally Bonded FRP Systems for Strengthening Concrete Structures (ACI 440.2R-17)

ACI 440.2R-08.2008. Guide for the Design and Construction of Externally Bonded FRP Systems for Strengthening Concrete Structures. American Concrete Institute, Farmington Hills.

Badan Standardisasi Nasional. 2011. Tata cara pembuatan dan perawatan benda uji beton di laboratorium (SNI 2493:2011). Jakarta: Dewan Standardisasi Nasional.

Han, A.L., dkk.2018. Penelitian pemanfaatan sheet dan rod.fiber untuk perkuatan balok T: A Review, Internasional Journal of Engineering. MacGregor,

Tudjono dkk. 2017. Revitalization of Cracked Flexural Members using Retrofitting and Synthetic Wrapping. Procedia Engineering, Volume 171, pp. 1123-1128.

Wang, P., Chen, H.,Zhou, Y., Wang, B., Jiang, M., ..Fan, H. (2018). Failure mechanisms of CFRP-wrapped protective concrete arches under static and blast loding : Experimental research. Composite Structures.

Anonim, 2013, Tata Cara Perhitungan Struktur c. Balok $\mathrm{BC} 1 \mathrm{~g}$ memiliki kekakuan awal sebesar $32485.21 \mathrm{~N} / \mathrm{mm}$ dan mengalami peningkatan nilai kekakuan setelah perkuatan menjadi $53823.53 \mathrm{~N} / \mathrm{mm}$ atau sebesar $65.68 \%$.

d. Balok $\mathrm{BC} 2 \mathrm{~g}$ memiliki kekakuan awal sebesar $25250.97 \mathrm{~N} / \mathrm{mm}$ dan mengalami peningkatan nilai kekakuan setelah perkuatan menjadi $52320 \mathrm{~N} / \mathrm{mm}$ atau sebesar $107.2 \%$.

4. Penambahan perkuatan CFRP pada balok $\mathrm{T}$ meningkatkan kekakuan balok tersebut yang digambarkan oleh peningkatan nilai frekuensi alami balok $\mathrm{T}$ baik pada perkuatan balok lentur maupun geser.

5. Penambahan perkuatan $C F R P$ pada balok $\mathrm{T}$ tidak hanya menambah kapasitas lentur maupun geser tetapi juga mempengaruhi perilaku dinamik balok $\mathrm{T}$ tersebut.

Beton Untuk Bangunan Gedung, Bandung. (SNI 2847-2013).

Biggs, J.M., 1964, Structural Dynamics, McCraw-Hill Book company, USA.

Cluogh, R.W., and Penzien, J., 1982, Dynamic of Structures, McCraw-Hill, Kogakusha.

Priyosulistyo., Bahan Kuliah, Program Sarjana Teknik Sipil, Fakultas Teknik, Universitas Gadjah Mada, Yogyakarta.

Mehdizadeh, M., 2009. Curvature Mode Shape Analyses of Damage in Structures, Thesis, RMIT University.

Nawy, E.G., 1990, Beton Bertulang Suatu Pendekatan Mendasar (diterjemahkan oleh Bambang Suryoatmono), Eresco, Bandung.

Paz, M., 1996. Dinamika Struktur, Teori dan Perhitungan. (diterjemahkan oleh Ir. Manu A.P.), Erlangga, Jakarta.

Saleh, F., 2000, Deteksi Lokasi Kerusakan Balok Beton Non-Prismatis dengan Perubahan Mode Kelengkungan, Tesis, Program Pasca Sarjana, Universitas Gadjah Mada, Yogyakarta.

Suhendro B., 1995, Struktur Dinamik, Bahan Kuliah, Program Sarjana Teknik Sipil, Fakultas Teknik, Universitas Gadjah Mada, Yogyakarta.

Supriyadi, B., 2008. Pengaruh Beban Sejumlah Orang Bernyanyi dan Berjoget Bersama pada Struktur Lantai Gedung Berbentang Panjang (Studi Kasus Gedung Grha Sabha Pramana UGM), journal Media Teknik Sipil,Yogyakarta.

Widorini, T., 2012. Karakteristik Dinamik Pelat Lantai semi Precast dengan perkuatan shear connector, Tesis, Program Pasca Sarjana, 
Universitas Gadjah Mada, Yogyakarta.

Arjanto., 2002. Perilaku Dinamik Balok Beton Bertulang retrofit dengan CFRP Wrap, Tesis, Program Pasca Sarjana, Universitas Gadjah Mada, Yogyakarta

Tuhuteru, E., 2013. Pengaruh shear connector terhadap Perilaku Dinamik Pelat Semi Pracetak, Tesis, Program Pasca Sarjana, Universitas Gadjah Mada, Yogyakarta

Paulinus, C., 2015. Perilaku Lentur Pelat Lantai Semi Precast Menggunakan Shear
Connector akibat Beban Dinamik, Tesis, Program Pasca Sarjana, Universitas Gadjah Mada, Yogyakarta. 